\title{
Comparing Acidovorax citrulli strains from melon and watermelon: Phenotypic characteristics, pathogenicity and genetic diversity
}

\author{
Luciano A. Melo, Nilvanira D. Tebaldi, Angela Mehta \& Abi S.A. Marques \\ Laboratório de Quarentena Vegetal, Embrapa Recursos Genéticos e Biotecnologia, Cx. Postal 02372, 70770-900, Brasília, \\ DF, Brazil
}

Author for correspondence: Abi S.A. Marques, e-mail: abi.marques@embrapa.br

\begin{abstract}
Melon and watermelon bacterial fruit blotch, incited by Acidovorax citrulli, is limited to some areas in Brazil but causes important losses, mainly in melon-producing regions. Although genetic diversity has been observed among strains belonging to the species, they are considered a homogeneous group based on the fact that they show only slight physiological or nutritional differences. The objective of this study was to compare Brazilian strains from melon and watermelon by means of biochemical, pathogenicity, serological and molecular assays. Fifteen biochemical tests, cross inoculation between strains and hosts, ELISA and repetitive sequence analysis (repPCR) with the primers REP, ERIC and BOX were conducted. No differences were revealed by nutritional characterization or serology, but cross inoculation showed different pathogenicity groups, which could explain high aggressiveness of the bacteria to melon crops in some regions. Molecular analysis by BOX-PCR clustered strains according to their geographical origin, while ERIC- and REP-PCR, analyzed together, indicated genetic diversity, but without geographical or host origin relationships. One test that could be used to verify the pathogenicity of strains by inoculating detached leaf petioles, showing results in $36 \mathrm{~h}$, is proposed here.
\end{abstract}

Key words: Citrullus lanatus, Cucumis melo, bacterial fruit blotch, DAS-ELISA, pathogenicity test, rep-PCR.

\section{INTRODUCTION}

Melon and watermelon bacterial fruit blotch is one of the most destructive diseases of these crops, causing melon yield losses of up to $100 \%$ (Sales Jr. \& Menezes, 2001). It is caused by Acidovorax avenae subsp. citrulli (Schaad et al. 1978) Willems et al. 1992. In 2008, Schaad et al. proposed a new classification for subspecies of $A$. avenae, where $A$. avenae subsp. citrulli was elevated to the species level, being reclassified as Acidovorax citrulli Schaad et al. 2008. Herein, we adopt this new nomenclature.

This bacteriosis was reported in Brazil in 1990 infecting watermelon (Citrullus lanatus L.) in São Paulo state (Robbs et al., 1991). Some years later, the disease was reported in another seven states: Minas Gerais, Rio Grande do Norte, Ceará, Pernambuco and Rio Grande do Sul (Mariano \& Silveira, 2004), Bahia (Mariano et al., 2004) and Roraima (Halfeld-Vieira \& Nechet, 2007). Burdman \& Walcott (2012), revising the related literature and reporting personal observations, stated that the disease occurs in 22 countries. The host range of $A$. citrulli is limited to the Cucurbitaceae (Latin \& Hopkins, 1995; Burdman \& Walcott, 2012).

Typical bacterial fruit blotch symptoms include water-soaked, olive-green lesions on fruit rinds, beginning as small ones, rapidly extending to internal fruit decay.
Seedlings show symptoms such as water-soaked lesions on cotyledons and hypocotyl, which can lead to the collapse of the emerging seedling. Symptoms on leaves are difficult to distinguish and do not cause leaf fall, but may be important inoculum reservoirs. Stems, petioles and roots are not normally infected (Latin \& Hopkins, 1995).

A. citrulli strains from melon and watermelon have been indiscriminately used for different assays independently of the host of origin, since no consistent distinction in terms of nutritional or physiological characters has been observed between them. Nevertheless, Walcott et al. (2000) observed genotypic differences among strains from melon, watermelon and squash using DNA fingerprinting obtained by pulse field gel electrophoresis (PFGE) and by fatty acid methyl ester (FAME). Walcott et al. (2004) obtained the same result by means of rep-PCR using the primer BOXA1R: they observed a group which contained only watermelon strains. Burdman et al. (2005) also characterized strains from Israel by PFGE and rep-PCR and confirmed that $A$. citrulli strains could be separated into two groups: the first one including watermelon strains, and the second, strains from the other hosts.

Concerning pathogenicity, Walcott et al. (2004) observed that watermelon strains are more aggressive in the same host than in melon or squash, while the aggressiveness of strains from the other hosts is equal for all hosts. 
Molecular characterization of a group of strains is highly useful to demonstrate genetic diversity at different classification levels, as well as to develop identification markers. Species-specific primers were developed for $A$. avenae (Walcott \& Gitaitis, 2000), and a pair of subspeciesspecific primers were described for the then subsp. citrulli (Schaad et al., 2000; Song et al., 2003; Bahar et al., 2008; Zhao et al., 2009). A very interesting use of molecular characterization is that described by Makizumi et al. (2011), which uses the rRNA $16 \mathrm{~S}$ sequence to characterize several strains from cucurbit that could be misidentified as $A$. citrulli.

Yield losses attributed to bacterial fruit blotch in Brazil have been more significant for melon than watermelon ever since the disease was first identified in the former crop (Viana et al., 2000). To better understand this disease complex, the relationship among strains from the two main hosts needs to be clarified, to identify similarities and/or differences which may explain the higher aggressiveness on melon crops in some regions. The main objective of this study was to compare Brazilian strains of $A$. citrulli from melon and watermelon, by means of a molecular evaluation using DNA fingerprints generated by the amplification of repetitive genomic sequences, to identify if differences are linked to geographical or host origin, and also by means of culture characteristics, nutritional and physiological tests and serology, as well as evaluating the strains aggressiveness to different hosts. Considering that pathogenicity tests are frequently time consuming, a faster assay for performing such characterization was evaluated.

\section{MATERIALS AND METHODS}

\section{Source of strains and storage conditions}

Acidovorax spp. strains and their characteristics are described in Table 1. A total of 22 strains were studied. This included 14 strains of $A$. citrulli from melon and five from watermelon including the type strain obtained from the Collection Française de Bactéries associées aux Plantes (CFBP). Three other strains were included as references: one of A avenae (Emb.C459-1) and two of $A$. valerianellae (CFBP 4723 and 4730). Strains were grown on 523 culture medium at $28^{\circ} \mathrm{C}$ for 48 hours and maintained on YDC slants covered with mineral oil and also archived at $-20^{\circ} \mathrm{C}$ in $20 \%$ glycerol (Schaad et al., 2001).

\section{Phenotypic characteristics and serology}

Nutritional and physiological tests were performed to detect differences among strains, previously identified as A. citrulli. Each culture was submitted to 15 conventional tests: Gram test, anaerobioses, growth at $41^{\circ} \mathrm{C}$, catalase, fluorescent pigment on King's B medium, gelatin hydrolysis, oxidase, reduction of nitrate, urease, arginine dihydrolase activity, glucose metabolism, levan production, utilization of sucrose, sorbitol and mannitol. Strains were also submitted to HR test in tobacco leaves, to the potato soft rot test (Schaad et al., 2001) and were cultivated in Hopkins specific medium (Hopkins et al., 2003).

Serological evaluation was carried out using the PathoScreen kit for DAS-ELISA (Agdia), according to the protocol provided by the manufacturer.

\section{Pathogenicity}

\section{Pathogenicity tests}

Three inoculation methods were compared to select the fastest one for a pathogenicity test, using one-month old melon plants cv. Amarelo Ouro and six strains of $A$. citrulli: Emb.A11-19, Emb.A11-21, Emb.A11-22, Emb. A11-23, Emb.C586 and Emb.C587: 1- classical cut of leaf apex followed by immersion in a bacterial suspension; 2scratching/wetting leaf abaxial surface with a suspensionsoaked gauze; 3- slight injury and deposition of a drop of suspension on detached petioles. Plants were maintained in damp chambers for 72 hours. Detached petioles were laid onto the surface of $1 \%$ water-agar in a Petri dish. Inoculations with sterile water were used as control.

\section{Cross inoculation}

For this experiment cvs. Amarelo Ouro (melon) and Charleston Gray (watermelon) were used and grown in $500 \mathrm{~g}$ pots. The experiment was entirely random, with 20 treatments resulting from cross inoculation among the strains of $A$. citrulli and the two hosts, in five replicates of one plant each. Bacterial strains used for cross inoculation are listed in Table 2, and were chosen to represent the two different origins and the five collections providing strains. Inoculation was performed by scratching/wetting the abaxial surface of the first three leaves from three-week-old plants with a suspension-soaked gauze. Concentration of the bacterial suspension was adjusted to $10^{6} \mathrm{CFU} / \mathrm{mL}$ with $0.005 \%$ Tween 20 . Before and following inoculation the plants were covered with plastic bags for 24 and 48 hours respectively. Disease severity was scored six days after inoculation based on the leaf area affected by the disease, on a scale of 1 to 5 (Buso et al., 2004). Based on the disease severity data, the Disease Index was calculated according to McKinney (1923). Statistical analyses was performed using the Scott-Knott test $(\mathrm{P}<0.01)$.

\section{PCR with specific primers}

PCR reactions were carried out using two pairs of specific primers: WFB1/ WFB2, which amplify a $360 \mathrm{bp}$ fragment from $A$. avenae and Comomonas spp. strains (Walcott \& Gitaitis, 2000); and SEQID4m/ SEQID5, which amplify a 246 bp fragment from A. citrulli strains (Schaad et al., 2000). Amplification reactions were performed as indicated by authors, in an MJ Research PTC-100 Thermal Cycler. Negative controls were included in all experiments, replacing the bacterial suspension with water. Amplification products were detected, stained and visualized by electrophoresis of $10 \mu \mathrm{L}$ aliquots through $1 \%$ agarose gels 


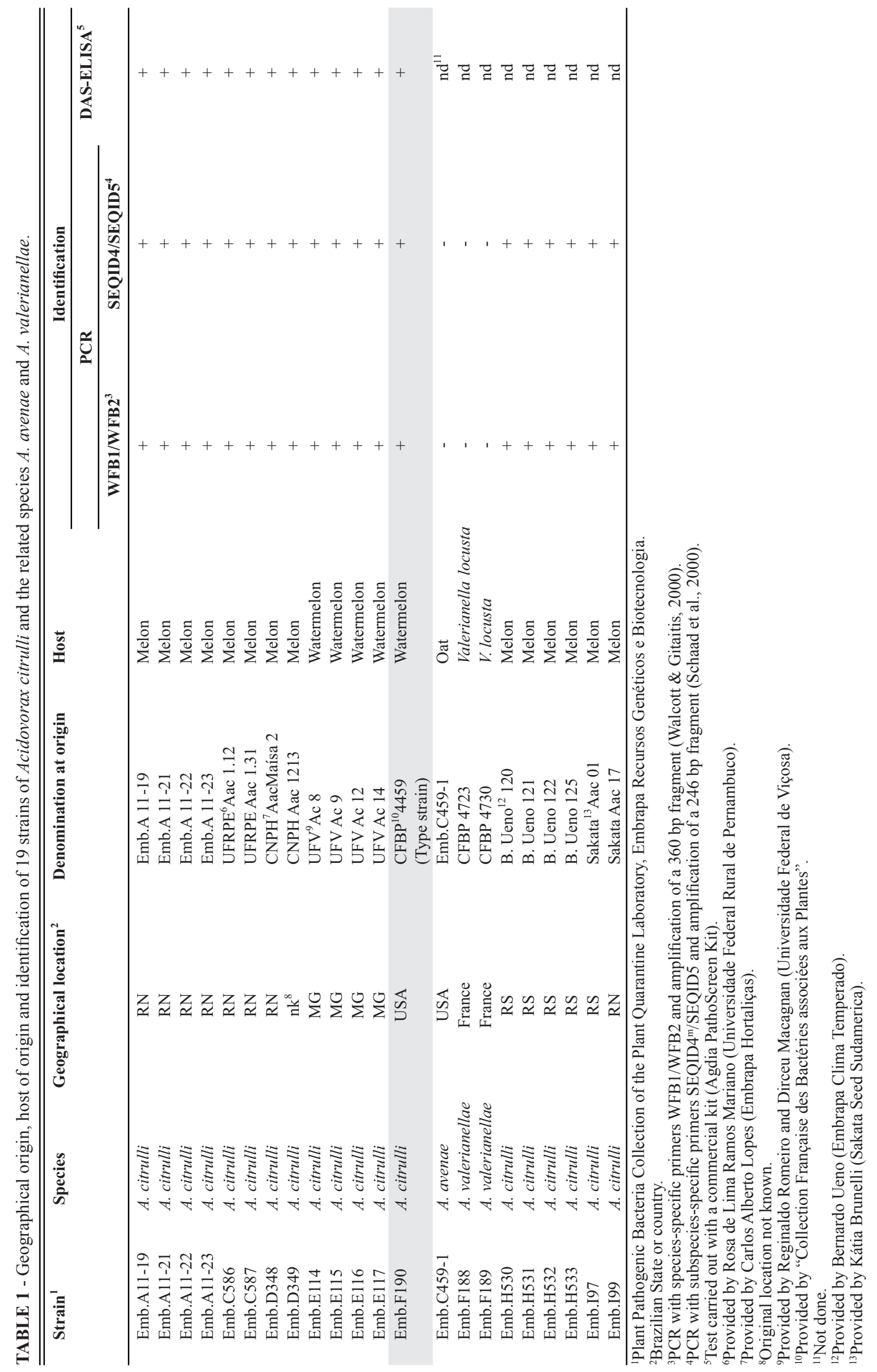


TABLE 2 - Characterization of Acidovorax citrulli strains based on bacterial fruit blotch severity in melon (cv. Amarelo Ouro) and watermelon (cv. Charleston Gray) seedlings.

\begin{tabular}{|c|c|c|c|c|c|}
\hline \multirow[t]{2}{*}{ Isolate } & \multirow[t]{2}{*}{ Original host } & \multicolumn{2}{|c|}{$\begin{array}{l}\text { Pathogenicity } \\
\text { in melon }\end{array}$} & \multicolumn{2}{|c|}{$\begin{array}{l}\text { Pathogenicity } \\
\text { in watermelon }\end{array}$} \\
\hline & & Score $^{1}$ & $\mathrm{DI}^{2}(\%)$ & Score & DI (\%) \\
\hline Emb.F190 & Watermelon & 2.47 & $49.33 \mathrm{Ab}^{3}$ & 1.80 & $36.00 \mathrm{Aa}$ \\
\hline Emb.E114 & Watermelon & 3.26 & $65.33 \mathrm{Bb}$ & 2.21 & $44.00 \mathrm{Aa}$ \\
\hline Emb.E115 & Watermelon & 3.65 & $73.33 \mathrm{Bb}$ & 2.65 & $53.33 \mathrm{Ba}$ \\
\hline Emb.E116 & Watermelon & 3.38 & $68.00 \mathrm{Ba}$ & 3.34 & $66.67 \mathrm{Ba}$ \\
\hline Emb.E117 & Watermelon & 3.60 & $72.00 \mathrm{Bb}$ & 1.93 & $38.67 \mathrm{Aa}$ \\
\hline Emb.A11-22 & Melon & 3.77 & $75.60 \mathrm{Bb}$ & 2.77 & $55.60 \mathrm{Ba}$ \\
\hline Emb.D348 & Melon & 2.77 & $55.57 \mathrm{Aa}$ & 2.87 & $57.83 \mathrm{Ba}$ \\
\hline Emb.C586 & Melon & 3.26 & $65.33 \mathrm{Bb}$ & 2.25 & $45.33 \mathrm{Aa}$ \\
\hline Emb.H530 & Melon & 4.87 & $97.33 \mathrm{Cb}$ & 2.13 & $42.67 \mathrm{Aa}$ \\
\hline Emb.I97 & Melon & 4.54 & $90.67 \mathrm{Cb}$ & 2.93 & $58.67 \mathrm{Ba}$ \\
\hline
\end{tabular}

${ }^{1}$ Means of five replications (one replication = one plant) and scores assigned by three evaluators per plant.

${ }^{2}$ DI: Disease index obtained six days after inoculation by scraping with gauze soaked in a bacterial suspension of three week-old plants, using a score scale described by Buso et al. (2004) and calculated according to McKinney (1923).

${ }^{3}$ Data followed by the same upper-case letter in columns and lower-case letter in rows do not denote significant differences among means according to the Scott-Knott test $(\mathrm{P}<0.01)$.

stained with ethidium bromide, visualized under UV light and image printed using Image Acquisition and Analysis Software, Labworks 4.6 (UVP Inc.). Each reaction was repeated at least twice. DNA standards $(1 \mathrm{~kb}$ plus DNA ladder, Invitrogen) were included in each electrophoresis gel.

\section{rep-PCR analysis}

Twenty-two strains were included in this study: 19 belonging to $A$. citrulli (including the type strain) and three other strains included as references (one of $A$. avenae and two of $A$. valerianellae; Table 1). Genomic bacterial DNA was extracted using the PWizard Genomic DNA Purification Kit (Promega). DNA concentration was determined using a NanoDrop ND100. All samples were dissolved in pure sterilized water (Milli Q), adjusted to $50 \mathrm{ng} / \mu \mathrm{L}$, and stored at $-20^{\circ} \mathrm{C}$.

The genetic relatedness of the 22 strains of Acidovorax spp. was investigated by rep-PCR according to Louws et al. (1994) using primers REP1R-I/REP2-I, ERIC1R/ERIC2 and BOXA1R, as described by those authors. Amplification reactions were performed in volumes of $25 \mu \mathrm{L}$, containing $1 \mu \mathrm{M}$ of a single BOX primer, or $1 \mu \mathrm{M}$ of each REP or ERIC primers, $0.2 \mathrm{mM}$ of dNTPs, PCR reaction buffer (10 $\mathrm{mM}$ Tris $\mathrm{HCl}, 50 \mathrm{mM} \mathrm{KCl}), 1.5 \mathrm{mM} \mathrm{MgCl}, 0.1 \mathrm{mg} / \mathrm{mL}$ bovine serum albumin, 1.5 U Taq DNA polymerase and 100 ng of bacterial DNA. Amplification was performed in an MJ Research PTC-100 thermal cycler programmed for an initial denaturation step of $5 \mathrm{~min}(7 \mathrm{~min}$ for $\mathrm{BOX})$ at $95^{\circ} \mathrm{C}$, followed by 30 cycles of $1 \mathrm{~min}$ at $94^{\circ} \mathrm{C}, 1 \mathrm{~min}$ at $40^{\circ} \mathrm{C}$, $52^{\circ} \mathrm{C}$ or $53^{\circ} \mathrm{C}$, (for REP, ERIC and BOX, respectively), $5 \mathrm{~min}(8 \mathrm{~min}$ for $\mathrm{BOX})$ at $65^{\circ} \mathrm{C}$, with a final elongation of $15 \mathrm{~min}$ at $65^{\circ} \mathrm{C}$. Negative controls were included in all experiments, replacing the bacterial suspension with water. Amplification products were detected, stained and visualized as described.
DNA fingerprints were compared according to the band patterns, but variations in intensity were not taken as differences. The results for each primer or primer pair were analyzed separately, but at one end REP and ERIC were combined. The data was analyzed with NTSYS (Exter Biological Software), and dendrograms were generated using the unweighted pair group method with averages (UPGMA).

\section{RESULTS AND DISCUSSION}

\section{Cultural, nutritional, physiological, serological and molecular identification}

All strains included in this study fitted with the general characteristics of the species $A$. citrulli. They were Gram-negative, obligate aerobes, and did not produce fluorescent pigment on King's B medium. Catalase was positive. Bacterial cells were rod-shaped; colonies were convex, beige-tan colored, round and non-mucoid. In Hopkins medium, a white precipitate occurred surrounding the colonies due to the presence of Tween-80, which facilitated identification.

A. citrulli induced HR on tobacco leaves, but did not produce potato soft rot. Results obtained from the biochemical tests also were characteristic of the species, except for reduction of nitrate to nitrite and utilization of mannitol. According to Schaad et al. (2008), utilization of mannitol is negative, but $A$. citrulli is the only species that presents a negative result for reduction of nitrate, which was not observed in this study. Additionally, strains from melon produced a darker and denser precipitate compared to strains from watermelon. This was the only and slight difference between the two groups of strains observed for nutritional characterization. Regarding the remaining tests, the results were positive for oxidase, urease and growth at 
$41^{\circ} \mathrm{C}$. The strains used ethanol and D-glucose as carbon sources, but results were negative for mannitol, sucrose, arginine and sorbitol, differing from the results found by Cavalcanti et al. (2005) for mannitol and sorbitol. These differences are probably due to variability that could be found within different groups of strains. However, nutritional and physiological differences within A. citrulli species are, at present, reported to be very few (Burdman \& Walcott, 2012).

DAS-ELISA, used here to confirm identification of strains, gave positive results for all strains included in the test.

The same identification was obtained by PCR with specific primers, with the amplification of both the 360 bp and $246 \mathrm{bp}$ fragments with primers WFB1/WFB2 and SEQID4 ${ }^{\mathrm{m}} / \mathrm{SEQID} 5$, respectively, for all $A$. citrulli strains (Table 1). Thus, despite the differences found in nutritional characterization, the correct identification of strains could be confirmed.

\section{Pathogenicity test}

Results of methods evaluated to establish a fast pathogenicity test are illustrated in Figure 1. Detached petiole inoculation was found to be the most efficient, with the first symptoms appearing 36 hours after inoculation. This test is proposed to be used to verify the pathogenicity of strains and to complete Koch's postulates when performing surveys. It is not time consuming and it is very easy to perform. In the petioles, there were water-soaked lesions, 2 $\mathrm{cm}$ in extension, sometimes with bacterial exudates (Figure 1A). Wounding and scratching the leaf abaxial surface with a suspension-soaked gauze induced symptoms 48 hours after inoculation. Symptoms on those leaves became visible as angular water-soaked lesions, light-green in color, in $80 \%$ of the plants (Figure 1B). Five days after inoculation, there were necrotic lesions with a yellow halo (Figure 1C). The least efficient test was cutting the leaf apex, which yielded symptoms only in $4 \%$ of the plants. In this case, necrosis on the leaf edges was observed after 12 days (data not shown).

\section{Cross inoculation}

Cross inoculation between strains from melon and watermelon and cultivars of those hosts indicated that the strains Emb.I97 and Emb.H530 were the most
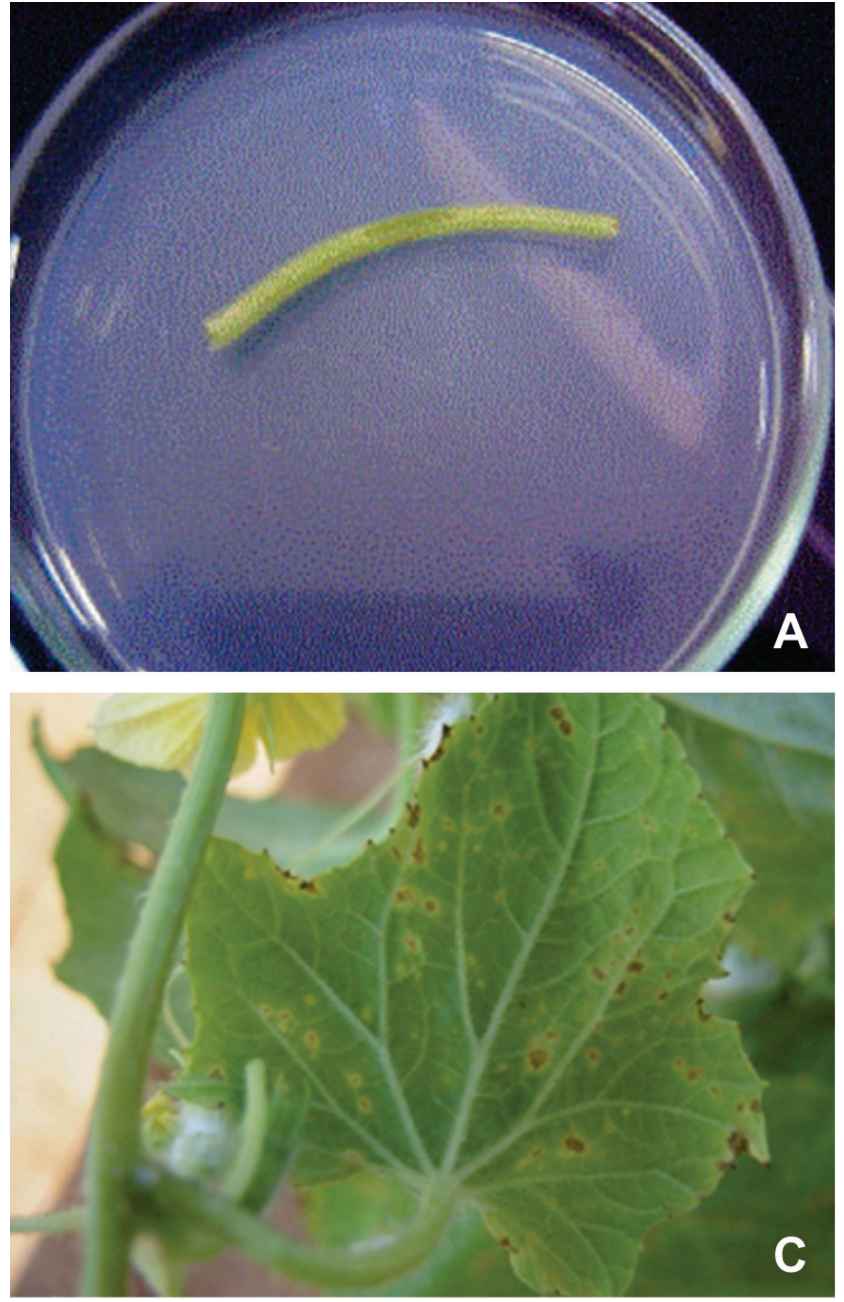

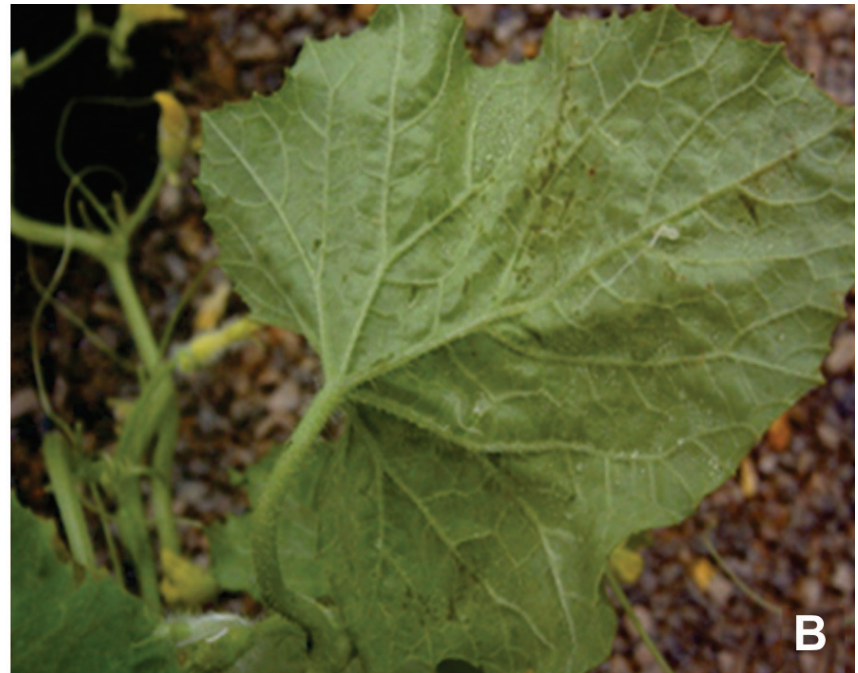

FIGURE 1 - Symptoms of bacterial fruit blotch of melon incited by Acidovorax citrulli. Inoculation to compare pathogenicity test methods. A. Water-soaked lesion on a detached petiole, 36 hours after inoculation by injury followed by deposition of a drop of suspension, and incubated on water-agar in a Petri dish; B. Watersoaked lesions on leaves inoculated by scraping with gauze soaked in a bacterial suspension, 48 hours after inoculation; C. Evolution of symptoms showed in B, five days later, to necrosis surrounded by a yellow halo. 
aggressive to melon, differing statistically from the other strains according to the Scott-Knott test $(\mathrm{P}<0.01)$ (Table 2). Strains Emb.E115, Emb.A11-22, Emb.D348, Emb.I97 and Emb.E116 were the most aggressive to watermelon, not differing statistically amongst them. Strains Emb.A1122, Emb.D348, Emb.E116 and Emb.F190 did not show any statistical difference in aggressiveness to both hosts. Except for strains Emb.E116 and Emb.D348, all strains studied, regardless of the host of origin, were more aggressive to melon than to watermelon. This is a result that does not agree with those obtained by Oliveira et al. (2007), when strains from watermelon incited high disease index on the original host. Walcott et al. (2004) also observed that strains from watermelon were more aggressive in this host than in melon and squash, while the severity of strains from the other species was the same for all hosts. The relative hostpathogen specificity reported by Burdman et al. (2005) and Oliveira et al. (2007) was not seen in this study. However, the very generalized strains' aggressiveness to melon may explain the high severity of the disease in this host in some Brazilian regions.

\section{Genetic characterization}

The genetic diversity of $22 \mathrm{~A}$. citrulli, A. avenae and $A$. valerianellae strains was investigated by rep-PCR. After amplification and visualization of PCR products, polymorphic bands were considered for analysis: 200 to $5000 \mathrm{bp}$ for 36 -REP; 300 to $5000 \mathrm{bp}$ for 42 -ERIC and 35-BOX. Individualized and combined analyses were performed for each of the primers. The BOX-PCR analysis was kept individualized and it is shown in the dendrogram of Figure 2. Considering the same trends indicated for data generated by REP- and ERIC-PCR, these data are presented combined in the dendrogram of Figure 3.

Data generated using the BOXA1R primer clustered strains according to their geographical origin, but not according to their host of origin. Considering a similarity index of $90 \%$, six groups were formed: group I corresponded to the type strain of $A$. citrulli from the USA (Schaad et al., 1978); group II included the strains from the Southern region (RS state), Southwestern region (MG state) and one strain from the Northeastern region (RN state); group III included seven strains from the Northeastern region ( $\mathrm{RN}$ state); strain

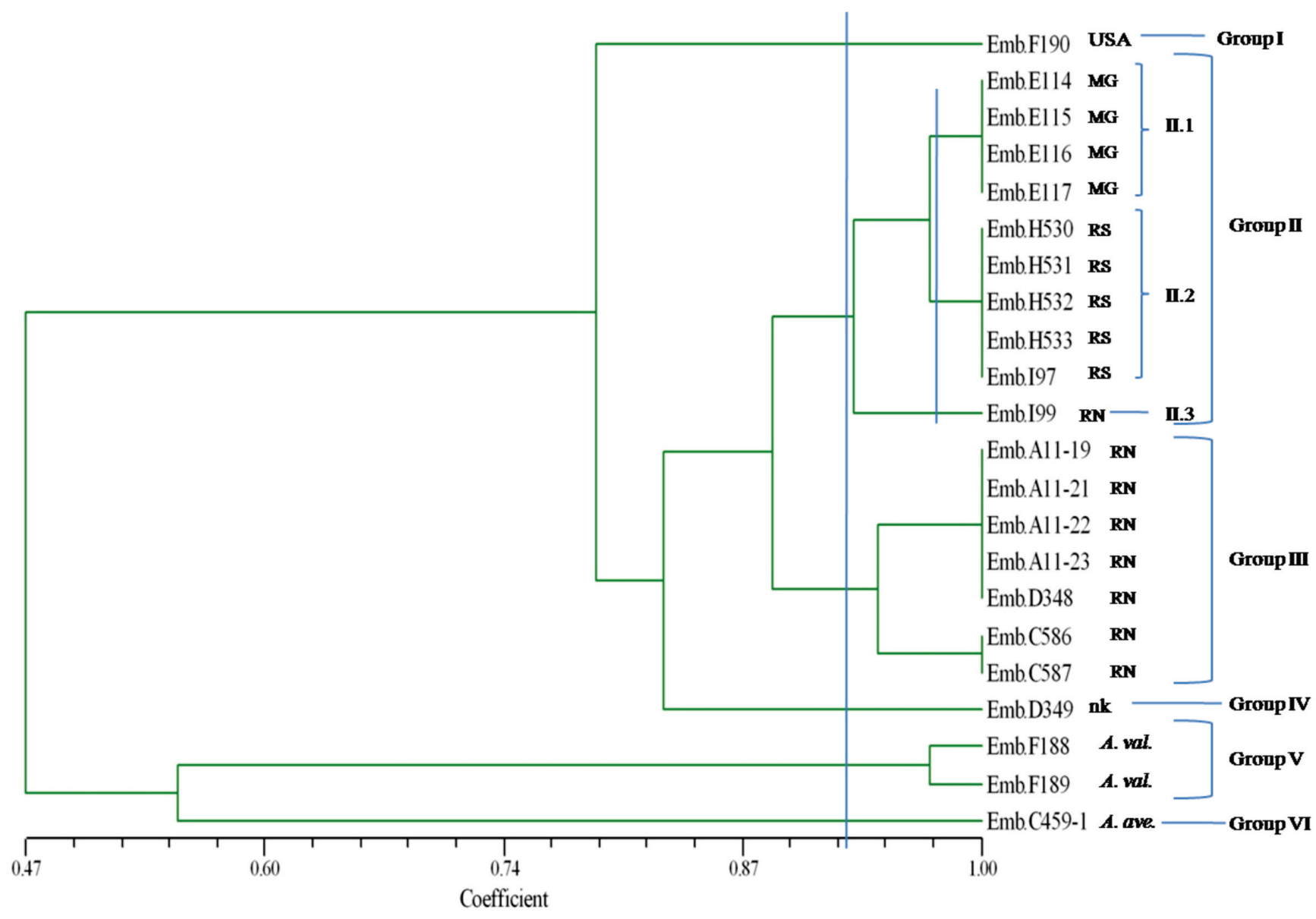

FIGURE 2 - Dendrogram constructed by comparing fingerprints of Acidovorax citrulli, A. avenae and A. valerianellae strains, obtained by BOX-PCR. Emb.F190 is the A. citrulli type strain (CFBP 4459). nk: Original location not known. A. val:: Acidovorax vallerianellae. A. ave.: Acidovorax avenae. 


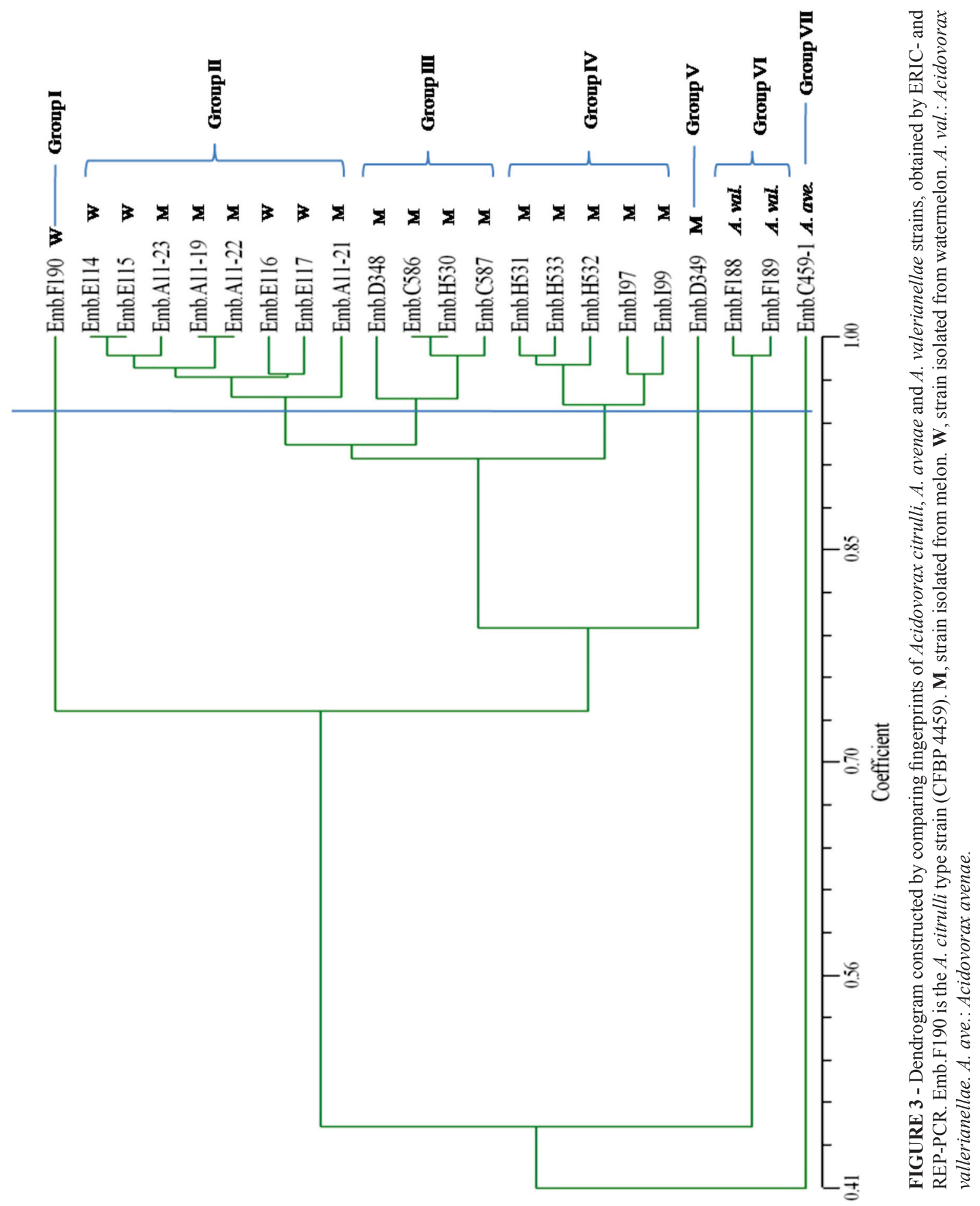


Emb. D349 formed group IV; group V corresponded to strains of $A$. valerianellae used as references; and group VI corresponded to the A. avenae strain, which was separated from the others at $55 \%$ of similarity. However, in carrying out a second evaluation of group II at $95 \%$ of similarity, three groups were observed: II.1, containing only strains from Minas Gerais state; II.2, with strains from Rio Grande do Sul state; and II.3, separating the Northeastern region strains. This supports our statement that this is a primer that clusters strains by their geographical origin. A similar result was reported for Xanthomonas albilineans, when strains were grouped according to their geographical origin by the aforementioned primer (Silva et al., 2007). Another kind of clustering is reported by Marques et al. (2008), where the BOXA1R primer grouped strains of Pseudomonas syringe and $P$. viridiflava group according to their genomic species, which were assigned by Gardan et al. (1999).

ERIC- and REP-PCR analysis demonstrated some genetic diversity among the strains included in this study, but without connection geography or host of origin. The dendrogram with combined data generated by the two primers yielded seven groups, considering 95\% similarity. Group I was formed by the type strain; group II, by four watermelon strains and four melon strains; group III, by four melon strains, where strain Emb.H530, the most aggressive to that host, is located; group IV was formed by five melon strains and includes strain Emb.I97, one of the most aggressive to both hosts (Table 2); finally, groups V, VI and VII corresponded to strain Emb.D349 and to the strains of $A$. valerianellae and A. avenae, respectively. Although there were fewer watermelon than melon strains studied here, they were clustered together in group II, except for the type strain. This is consistent with, but not as clear as, those results reported by Walcott et al. (2004), Burdman et al. (2005) and Feng et al. (2009). Those authors found genetic clustering of $A$. citrulli strains from watermelon, with another group including strains from other hosts. The large number of strains and the highly diverse geographical origin analyzed by Walcott et al. (2004) and Feng et al. (2009), compared to the equivalent number of hosts of origin analyzed by Burdman et al. (2005), may account for the differences in the clustering of strains reported by these authors.

The present study confirms that there is important genetic diversity within the species A. citrulli, as well as differences in aggressiveness, that should be taken into account when choosing strains to use in melon and watermelon resistance breeding programs. The results suggest also that some relationship exists between variants of the pathogen and melon/watermelon reactions, expressed in different regions of the country.

\section{ACKNOWLEDGEMENTS}

N.D. Tebaldi was supported by a grant from Financiadora de Estudos e Projetos - Finep. We are grateful to Joanice P.S. Damasceno and Alexandre P. Mendes for their technical help during the assays; to Wesley R. Souza for image editing; and to Drs. Rosa de Lima Ramos Mariano (UFRPE), Carlos Alberto Lopes (Embrapa Hortaliças), Reginaldo Romeiro (in memoriam) and Dirceu Macagnan (UFV), Bernardo Ueno (Embrapa Clima Temperado) and Kátia Regiane Brunelli (Sakata Seed Sudamerica) for kindly providing the strains.

\section{REFERENCES}

Bahar O, Efrat M, Hadar E, Dutta B, Walcott RR, Burdman S (2008) New subspecies-specific polymerase chain reaction-based assay for the detection of Acidovorax avenae subsp. citrulli. Plant Pathology 57:754-763.

Burdman S, Kots N, Kritzman G, Kopelowitz J (2005) Molecular, physiological, and host range characterization of Acidovorax avenae subsp. citrulli strains from watermelon and melon in Israel. Plant Disease 89:1339-1347.

Burdman S, Walcott R (2012) Acidovorax citrulli: Generating basic and applied knowledge to tackle a global threat to the curcubit industry. Molecular Plant Pathology 13:805-815.

Buso GSC, Nass LL, Marques ASA, Lopes CA, Buso JA (2004) Avaliação de genótipos de melão, visando identificar fontes de resistência a Acidovorax avenae subsp. citrulli. Brasília, DF. Embrapa Recursos Genéticos e Biotecnologia. Comunicado Técnico 116.

Cavalcanti MT, Silveira EB, Mariano RLR, Viana IO (2005) Crescimento de Acidovorax avenae subsp. citrulli sob diferentes temperaturas, $\mathrm{pH}$, concentração de cloreto de sódio e fontes de carbono. Ciência Rural 35:1313-1318.

Feng J, Schuenzel EL, Li J, Schaad NW (2009) Multilocus sequence typing reveals two evolutionary lineages of Acidovorax avenae subsp. citrulli. Phytopathology 99:913-920.

Gardan L, Shafik H, Belouin S, Brosch R, Grimont F, Grimont PAD (1999) DNA relatedness among the pathovars of Pseudomonas syringae and description of Pseudomonas tremae sp. nov. and Pseudomonas cannabina sp. nov. (ex. Sutic and Dowson 1959). International Journal of Systematic Bacteriology 49:469-478.

Halfeld-Vieira BA, Nechet KL (2007) Mancha-aquosa da melancia em Roraima. Fitopatologia Brasileira 32:268.

Hopkins DL, Cucuzza JD, Waterson JC (2003) Wet seed treatment with peroxyacetic acid for the control of bacterial fruit blotch and other seedborne diseases of watermelon. Plant Disease 87:14951499.

Latin RX, Hopkins DL (1995) Bacterial fruit blotch of watermelon: The hypothetical exam question becomes reality. Plant Disease 79:761-765.

Louws F, Fullbright DW, Stephens CT, Bruijn FJ (1994) Specific genomic fingerprints of phytopatogenic Xanthomonas and Pseudomonas pathovars and strains generated with repetitive sequences and PCR. Applied and Environmental Microbiology 60:2286-2295.

Mariano RLR, Silva VAV, Silva AMF, Medeiros FHV, Viana IO (2004) Ocorrência da mancha-aquosa do melão na Bahia. Fitopatologia Brasileira 29:147-148. 
Mariano RLR, Silveira EB (2004) Mancha-aquosa: Importante bacteriose do meloeiro no Brasil. Anais daAcademia Pernambucana de Ciência Agronômica 1:79-88.

Marques ASA, Marchaison A, Gardan L, Samson R (2008) BOX-PCR-based identification of bacterial species belonging to Pseudomonas syringe and P. viridiflava group. Genetics and Molecular Biology 31:106-115.

McKinney HH (1923) Influence of soil, temperature and moisture on infection of wheat seedlings by Helminthosporium sativum. Journal of Agricultural Research 26:195-218.

Makizumi Y, Igarashi M, Gotoh K, Murao K, Yamamoto M, Udonsri N, Ochiai H, Thummabenjapone P, Kaku H (2011) Genetic diversity and pathogenicity of cucurbit-associated Acidovorax. Journal of General Plant Pathology 77:24-32.

Oliveira JC, Silveira EB, Mariano RLR, Cardoso E, Viana IO (2007) Caracterização de isolados de Acidovorax avenae subsp. citrulli. Fitopatologia Brasileira 32:480-487.

Robbs CF, Rodrigues Neto J, Ramos RS, Sinigaglia C (1991) Mancha bacteriana da melancia no estado de São Paulo, causada por Pseudomonas pseudoalcaligenes subsp. citrulli. Fitopatologia Brasileira 16:48.

Sales Jr R, Menezes JB (2001) Mapeamento das doenças fúngicas, bacterianas e viróticas do cultivo do melão do Estado do RN. Mossoró, RN. Escola Superior de Agricultura de Mossoró.

Schaad NW, Jones JB, Chun W (2001) Laboratory Guide for Identification of Plant Pathogenic Bacteria. $3^{\text {rd }}$ ed. ST. Paul, MN, USA. APS Press.

Schaad NW, Postnikova E, Sechler A, Clafin LE, Vidaver AK, Jones JB, Agarkova I, Ignatov A, Dickstein E, Ramundo BA (2008) Reclassification of subspecies of Acidovorax avenae as A. avenae (Manns 1905) emend., A. cattleyae (Pavarino, 1911) comb. nov., A. citrulli (Schaad et al., 1978) comb. nov., and proposal of $A$. oryzae sp. nov. Systematic and Applied Microbiology 31:434-446.

Schaad NW, Song WY, Hatziloukas E (2000) PCR primers for detection of plant pathogenic species and subspecies of Acidovorax.
US Patent 6:146, 834.

Schaad NW, Sowell Jr G, Goth RW, Colwell RR, Webb E (1978) Pseudomonas pseudoalcaligenes subsp. citrulli subsp. nov. International Journal of Systematic Bacteriology 28:117-125.

Silva MS, Bedendo IP, Casagrande MV (2007) Caracterização molecular e patogênica de isolados de Xanthomonas albilineans (Ashby) Dowson, agente causal da escaldadura das folhas da cana de açúcar. Summa Phytopathologica 33:341-347.

Song WY, Sechler AJ, Hatziloukas E, Kim HM, Schaad NW (2003) Use of PCR for rapid identification of Acidovorax avenae and $A$. avenae subsp. citrulli. In: Iacobellis NS, Collmer A, Hutcheson SW, Mansfield JW, Morris CE, Murillo J, Schaad NW, Stead DE, Surico G, Ullrich MS (Eds.) Pseudomonas syringae and Related Pathogens. Dordrecht, The Netherlands. Kluwer Academic Publishers. pp. 531-543.

Viana FMP, Santos AA, Cardoso JE, Freire FCO, Lopes CA (2000) Surto de mancha-aquosa em frutos de melão nos Estados do Ceará e do Rio Grande do Norte: Recomendações preliminares de controle. Fortaleza, CE. Embrapa Agroindústria Tropical. Comunicado Técnico $\mathrm{n}^{\circ} 50$.

Walcott RR, Fessehaie A, Castro AC (2004) Differences in pathogenicity between two genetically distinct groups of Acidovorax avenae subsp. citrulli on cucurbit hosts. Journal of Phytopathology 152:277-285.

Walcott RR, Gitaitis RD (2000) Detection of Acidovorax avenae subsp. citrulli in watermelon seed using immunomagnetic separation and the polymerase chain reaction. Plant Disease $84: 470-474$.

Walcott RR, Langston Jr DB, Sanders Jr FH, Gitaitis RD (2000) Investigating intraspecific variation of Acidovorax avenae subsp. citrulli using DNA fingerprinting and whole cell fatty acid analysis. Phytopathology 90:191-196.

Zhao T, Feng J, Sechler A, Randhawa P, Li J, Schaad NW (2009) An improved assay for detection of Acidovorax citrulli in watermelon and melon seed. Seed Science and Technology 37:337-349. 